\title{
Editorial "pituitary apoplexy—are visual deficits the only indication for emergent surgical intervention?"
}

\author{
Joachim Oertel ${ }^{1} \cdot$ Fritz Teping $^{1}$
}

Received: 6 January 2022 / Accepted: 7 January 2022 / Published online: 24 January 2022

(c) The Author(s) 2022

With 2-3\%, the initial haemorrhagic presentation of patients with pituitary adenomas is a rare finding [2]. Khawari and colleagues present interesting data of a retrospective multicentre cohort study on management, clinical and oncologic outcomes in such cases. In this study, patients with immediate surgical intervention were compared to those who underwent surgery within three months and with only conservative treatment. Subgroup analysis revealed comparable outcomes for all groups regarding visual and endocrinological findings. Interestingly, patients with subacute surgical therapy within three months showed higher rates of further oncological treatment - but without reaching statistical significance. However, $76 \%$ of the patients treated conservatively only did not require any additional treatment at all. Consequently, the authors suggest decision-making on the treatment modality based on visual symptoms rather than oncological aspects.

Surgery in the acute phase is mainly aimed at an early decompression of the visual apparatus or cranial nerves [1]. Reported outcomes prove an effective recovery of up to $94 \%$ of visual symptoms depending on surgical timing [3, 8 , 9]. Endocrinological improvement is less pronounced with partial recovery rates of up to $23 \%$ [7, 8]. However, in our opinion, devastating headaches - as the main symptom of pituitary apoplexy - tend to move into the background in scientific reports. This may be attributed to the limited prospective long-term relevance for the patient. However, in our experience, early surgery is the most effective strategy for pain relief in these patients. Regarding low surgery-related complication rates in experienced high-volume centres,

This article is part of the Topical Collection on Pituitaries

Joachim Oertel

Fritz Teping

fritz.teping@gmail.com

1 Department of Neurosurgery, Saarland University Medical Centre, Kirrbergerstraße, Building 90.5, 66421 Homburg, Germany surgical treatment for pain resolution also appears as an essential indication.

Oncologic control somewhat resembles a secondary goal of emergent surgery. The presented study shows that the percentage of patients requiring further oncologic treatment is similar in the surgical versus non-surgical group. This aspect emphasises that the indication setting for emergent surgery depends somewhat on clinical factors than oncologic control. However, a simultaneous tumour resection would be favourable if acute surgery is conducted for visual or pain symptom relief. In this context, endoscopic surgery can be beneficial due to reliable anatomical identifications in highdefinition visualisation while preserving endocrinological function [4-6].

As recognised by the authors, the heterogeneous treatment strategies and case-based decisions limit the scientific evaluation. However, the presented data should be considered an accurate reflection of current practice. On the one hand, the presented results underline the effectiveness of such individual treatment decisions. On the other hand, since prospective, randomised investigations are challenging, current recommendations are mainly based on expert opinions. Until the relevant data is available, our recommendation for emergent surgical intervention includes the presence of refractory headaches, especially in combination with visual deficits and endocrinological dysregulation.

Funding Open Access funding enabled and organized by Projekt DEAL.

\section{Declarations}

Conflict of interest The authors declare no competing interests.

Open Access This article is licensed under a Creative Commons Attribution 4.0 International License, which permits use, sharing, adaptation, distribution and reproduction in any medium or format, as long as you give appropriate credit to the original author(s) and the source, provide a link to the Creative Commons licence, and indicate if changes were made. The images or other third party material in this article are 
included in the article's Creative Commons licence, unless indicated otherwise in a credit line to the material. If material is not included in the article's Creative Commons licence and your intended use is not permitted by statutory regulation or exceeds the permitted use, you will need to obtain permission directly from the copyright holder. To view a copy of this licence, visit http://creativecommons.org/licenses/by/4.0/.

\section{References}

1. Barkhoudarian G, Kelly DF (2019) Pituitary apoplexy. Neurosurg Clin N Am 30:457-463

2. Bills DC, Meyer FB, Laws ER Jr, Davis DH, Ebersold MJ, Scheithauer BW, Ilstrup DM, Abboud CF (1993) A retrospective analysis of pituitary apoplexy. Neurosurgery 33:602-608 discussion 608-609

3. Gondim JA, de Albuquerque LAF, Almeida JP, Bulcao T, Gomes E, Schops M, Vasconcelos R, da Paz F, Guimaraes SB (2017) Endoscopic endonasal surgery for treatment of pituitary apoplexy: 16 years of experience in a specialized pituitary center. World Neurosurg 108:137-142

4. Linsler S, Hero-Gross R, Friesenhahn-Ochs B, Sharif S, Lammert F, Oertel J (2017) Preservation of hormonal function by identifying pituitary gland at endoscopic surgery. J Clin Neurosci 43:240-246

5. Linsler S, Szameitat N, Senger S, Oertel J (2018) Visualization and identification of the pituitary gland tissue in endonasal pituitary surgery: is there a difference between high-definition endoscopy and microscopy? World Neurosurg 116:e921-e928

6. Linsler S, Senger S, Hero-Gross R, Steudel WI, Oertel J (2020) The endoscopic surgical resection of intrasellar lesions conserves the hormonal function: a negative correlation to the microsurgical technique. J Neurosurg Sci 64:515-524

7. Liu ZH, Chang CN, Pai PC, Wei KC, Jung SM, Chen NY, Chuang CC (2010) Clinical features and surgical outcome of clinical and subclinical pituitary apoplexy. J Clin Neurosci 17:694-699

8. Rutkowski MJ, Kunwar S, Blevins L, Aghi MK (2018) Surgical intervention for pituitary apoplexy: an analysis of functional outcomes. J Neurosurg 129:417-424

9. Semple PL, Webb MK, de Villiers JC, Laws ER Jr (2005) Pituitary apoplexy. Neurosurgery 56:65-72 discussion 72-63

Publisher's Note Springer Nature remains neutral with regard to jurisdictional claims in published maps and institutional affiliations. 